\title{
Regulation of serum leptin and its role in the hyperphagia of lactation in the rat
}

\author{
R G P Denis ${ }^{1,2}$, G Williams ${ }^{2}$ and R G Vernon ${ }^{1}$ \\ ${ }^{1}$ Hannah Research Institute, Ayr KA6 5HL, UK \\ ${ }^{2}$ Diabetes and Endocrinology Research Group, Department of Medicine, University of Liverpool, Liverpool L69 3GA, UK \\ (Requests for offprints should be addressed to R G Vernon; Email: vernonr@hri.sari.ac.uk)
}

\begin{abstract}
The factors regulating serum leptin concentration and its relationship to the hyperphagia of lactation have been investigated in rats. Lactation results in hypoleptinaemia and loss, or at least marked attenuation, of the nocturnal rise in serum leptin. Litter removal resulted in a fall in food intake and restoration of the nocturnal rise in serum leptin. Returning the litter to the mother after a 48-h absence increased food intake and began to reinitiate milk production, but the nocturnal serum leptin levels were still increased at $48 \mathrm{~h}$ after litter restoration. Adjusting litter size to four, eight, ten or fourteen pups at parturition resulted in different rates of litter growth and food intake during the subsequent lactation, but had no effect on the degree of hypoleptinaemia. Reducing litter size from ten to four pups at mid-lactation resulted in a transient increase in both serum leptin and pup growth rate, while food intake fell to a level found in rats suckling four pups
\end{abstract}

throughout lactation. Reducing milk production by injection of bromocriptine increased serum leptin, but did not restore the nocturnal rise in serum leptin; food intake decreased, but remained much higher than in nonlactating rats. Feeding a varied, high-energy diet resulted in a decrease in the weight of food ingested, but no change in calorie intake, and had no effect on the hypoleptinaemia. These studies suggested that the hypoleptinaemia of lactating rats is due to negative energy balance, but the loss of the nocturnal rise in serum leptin is due to the suckling stimulus. The negative energy balance of lactation does not appear to be caused by a physical constraint on food intake. While the hypoleptinaemia should facilitate the hyperphagia of lactation, other orexigenic signals must also be involved.

Journal of Endocrinology (2003) 176, 193-203

\section{Introduction}

Lactation increases greatly the nutrient needs of an animal; in the rat, for example, the demands of the mammary gland can exceed those of the rest of the body (Wade \& Schneider 1992, Barber et al. 1997). This increase in nutrient requirement is usually met primarily by increased food intake (Chilliard 1986, Wade \& Schneider 1992, Barber et al. 1997); in rats, food intake typically increases fourfold to over $60 \mathrm{~g} /$ day at peak lactation. Additionally, there are adaptations to improve the metabolic efficiency of the animal and to favour nutrient utilization by the mammary gland; for example, rats show decreased thermogenesis in brown adipose tissue (Trayhurn 1989), decreased lipogenesis in white adipose tissue, hypothyroidism and hypoinsulinaemia (Williamson \& Lund 1994, McNamara 1995, Vernon \& Pond 1997). Nevertheless, laboratory rats are usually in a modest degree of negative energy balance during lactation, mobilizing about $1 \mathrm{~g}$ adipose tissue lipid per day to supplement nutritional needs (Barber et al. 1997).
The causes of hyperphagia in lactation are not well understood. One possibility is a decreased secretion of the adipocyte hormone, leptin (Zhang et al. 1994), which acts on various hypothalamic nuclei to decrease appetite (Ahima 2000, Ahima \& Flier 2000, Ahima et al. 2000, Havel 2000, Spiegelman \& Flier 2001). Indeed, the daytime serum leptin concentration has been reported to decrease by $20-75 \%$ during lactation in the rat (Kawai et al. 1997, Pickavance et al. 1998, Terada et al. 1998, Woodside et al. 1998, 2000, Brogan et al. 1999, Herrera et al. 2000), although others found no change (Chien et al. 1997, Carmen-Garcia et al. 2000). Rats, however, normally consume $80 \%$ or more of their food at night (Kimura et al. 1970, Bruckdorfer et al. 1974) and this pattern of eating is retained during lactation (Strubbe \& Gorissen 1980, Munday \& Williamson 1983, Pickavance et al. 1996, 1998). Both adipose tissue leptin mRNA expression (Saladin et al. 1995, Pickavance et al. 1998, Xu et al. 1999) and serum leptin concentration (Pickavance et al. 1998, Xu et al. 1999, Nagatani et al. 2000, Nishiyama et al. 2000, Mastronadi et al. 2000, Pu et al. 2000, 
Johnstone \& Higuchi 2001, Kalsbeek et al. 2001) show a diurnal rhythm in fed rats, increasing at night. The nocturnal increase in leptin is dependent on food intake, as the rise in leptin mRNA in adipocytes was not observed in fasted rats (Saladin et al. 1995). Furthermore, restricting feeding to a 6-h period during the day caused the rise in serum leptin to occur during the day, concurrently with food consumption (Xu et al. 1999). However, a subsequent study suggested that food intake is not the only factor, and implicates the suprachiasmatic nucleus, possibly acting via the sympathetic nervous system, in regulating the diurnal rhythm of leptin secretion (Kalsbeek et al. 2001).

The precise function of the nocturnal rise in serum leptin is unclear, but it may act to put some constraint on food intake, or perhaps to increase energy expenditure. Whatever, the nocturnal rise in serum leptin found in fed, non-lactating rats is lost during lactation (Pickavance et al. 1998, Johnstone \& Higuchi 2001), and so may be an important factor facilitating the hyperphagia.

Leptin may also have a role in adaptations that increase metabolic efficiency during lactation. Leptin administration prevents both the fall in thyroid hormone secretion (Ahima 2000, Ahima \& Flier 2000, Ahima et al. 2000, Flier et al. 2000) and the decrease in brown adipose tissue thermogenesis (Ahima \& Flier 2000, Ahima et al. 2000, Havel 2000, Spiegelman \& Flier 2001) which occur during fasting.

The objectives of this study were to clarify further the role of leptin in the hyperphagia of lactation and to identify factors responsible for the hypoleptinaemia. While it has been suggested that the decreased daytime serum leptin during lactation is due to the energy demands of the mammary gland, rather than the suckling stimulus (Brogan et al. 1999, Woodside et al. 2000), the factors responsible for the attenuation of the nocturnal rise in leptin have not been defined. We have therefore used a variety of manipulations designed to induce changes in energy balance and suckling intensity. These comprised changing the intensity of the suckling stimulus by removing the litter and varying litter size, feeding a varied, high-energy diet (to try to increase energy intake), and suppression of prolactin secretion and hence milk production using bromocriptine (Cowie et al. 1980). The findings provide evidence for negative energy balance being a key factor responsible for the daytime hypoleptinaemia of lactation, whereas the attenuation of the nocturnal rise in leptin is due to the suckling stimulus. Furthermore, leptin appears to facilitate rather than directly cause the hyperphagia of lactation.

\section{Materials and Methods}

Animals

Wistar rats (original stock from A Tuck \& Sons Ltd, Rayleigh, Essex, UK) were raised in-house at the Hannah
Research Institute, Ayr, UK. Rats were fed a standard chow ad libitum (CRM diet; Labsure, Poole, Dorset, UK), which contained $3 \cdot 2 \mathrm{kcal} / \mathrm{g}$. In one experiment, rats were given a high-energy diet, which comprised standard chow as before, plus cheese crackers $(5 \cdot 3 \mathrm{kcal} / \mathrm{g})$, chocolate $(5.3 \mathrm{kcal} / \mathrm{g})$ and peanuts $(6.0 \mathrm{kcal} / \mathrm{g})$; all components were given ad libitum. Animals were maintained on $12 \mathrm{~h}$ light:12 h darkness schedules, with the light period from $0700 \mathrm{~h}$ to $1900 \mathrm{~h}$ or from $1900 \mathrm{~h}$ to $0700 \mathrm{~h}$. At the time of experimentation, rats had been exposed to their specific light:darkness regimens for a minimum of 4 weeks. Animals in the dark between $0700 \mathrm{~h}$ and $1900 \mathrm{~h}$ were exposed to minimal disturbance. Animals were mated at 2-3 months of age, and the number of pups per litter was adjusted to ten within $24 \mathrm{~h}$ after parturition, unless stated otherwise. In one experiment, pups were removed from their mothers for $48 \mathrm{~h}$; during this period the pups were kept with foster mothers. Rats were accustomed to frequent handling, daily weighing and food intake measurements prior to the experimental period. Control, virgin rats were randomly cycling, and were of the same age as lactating rats. When given, bromocriptine $(500 \mu \mathrm{g}$; Sigma-Aldrich Co. Ltd, Poole, Dorset, UK) was injected subcutaneously twice daily at $0900 \mathrm{~h}$ and $1700 \mathrm{~h}$.

Rats were killed by cervical dislocation at $0900-1000 \mathrm{~h}$ and trunk blood was collected. In some experiments, blood samples (no more than $0.5 \mathrm{ml}$ ) were obtained from the tail vein. For this, rats were lightly anaesthetized using halothane $(2-3 \%$ in air). The tail was cut with a sharp scalpel no more than $2 \mathrm{~mm}$ from the tip, and blood collected. Following this, light pressure was applied to the wound until bleeding ceased. Rats were sampled no more than three times by this procedure and no more than once in a 24-h period.

Further details of individual experiments are given in the Figure and Table legends. All procedures were approved by the Ethical Review Committee of the Hannah Research Institute.

\section{Serum hormone assays}

Serum leptin, insulin and thyroxine $\left(\mathrm{T}_{4}\right)$ levels were determined by radioimmunoassay using kits from Linco Research Inc., MO, USA (distributed by Biogenesis, Poole, Dorset, UK), and for $\mathrm{T}_{4}$ from IDS Ltd (Boldon, Tyne and Wear, UK).

\section{Statistical analyses}

Data are expressed as means \pm S.E.M. When appropriate, results were analysed by ANOVA; factors and their interactions are given in Figure and Table legends. In some cases results were analysed by Student's $t$-test. A $P$ value of 0.05 or less was considered as significant. 


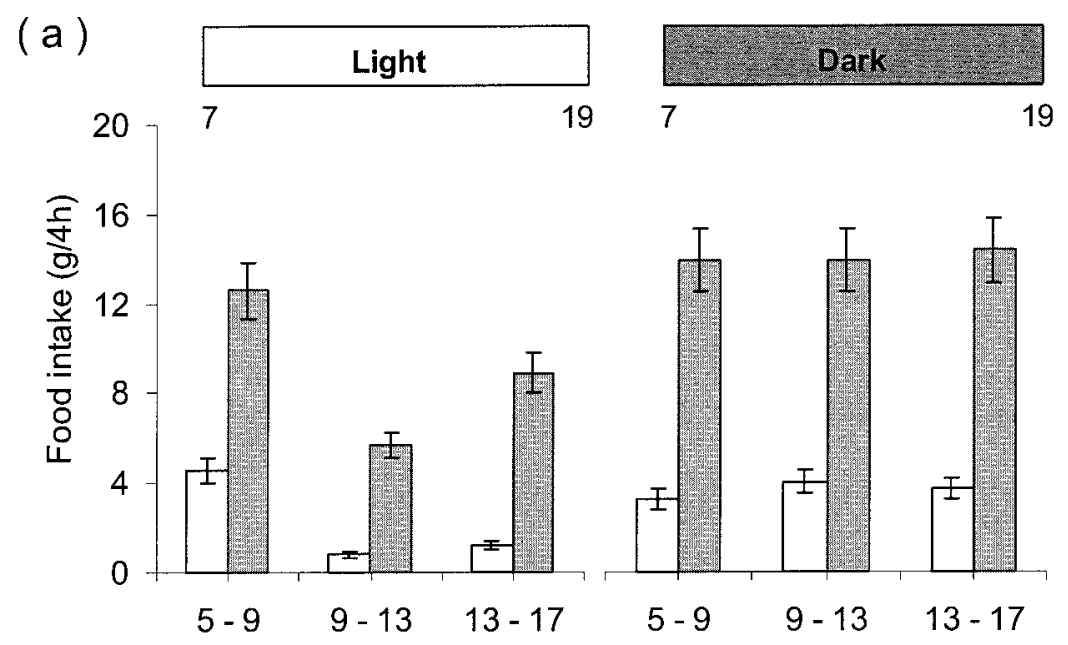

Clock time (h)

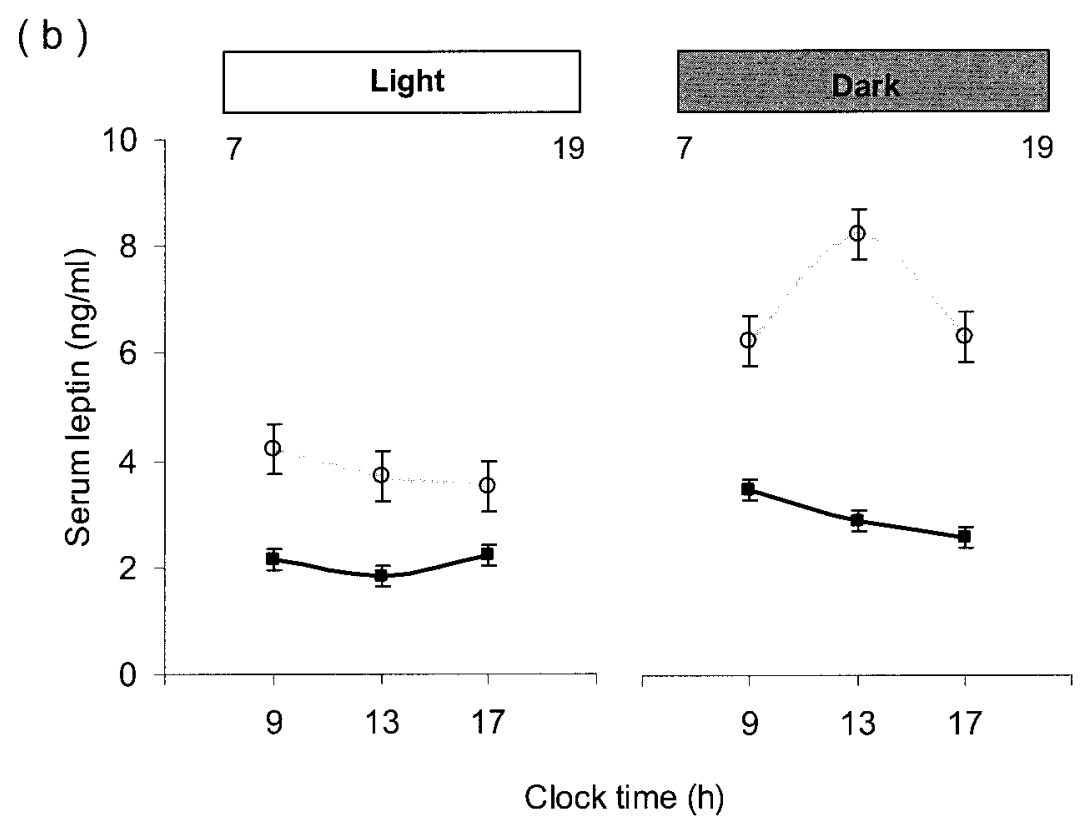

Figure 1 Diurnal changes in (a) food intake and (b) serum leptin in lactating (shaded columns/solid squares) and non-lactating (open columns/open circles) rats. Two groups of lactating and non-lactating rats were used; one group of each was exposed to a light period from $0700 \mathrm{~h}$ to $1900 \mathrm{~h}$ and the other group from $1900 \mathrm{~h}$ to $0700 \mathrm{~h}$. Blood was obtained from rats by tail bleeding. Each rat was sampled at $0900 \mathrm{~h}, 1300 \mathrm{~h}$ and $1700 \mathrm{~h}$; each sample was taken on a different day over a 3-day period. Studies were performed between 11 and 14 days of lactation. Food intake was measured over 4-h periods, hence the period $0500 \mathrm{~h}$ to $0900 \mathrm{~h}$ includes both a light and a dark phase. Results were analysed by ANOVA with state, period (light or dark) and time of sampling and their interactions as factors. Results are expressed as means \pm S.E.M. of eight observations.

\section{Results}

\section{Diurnal changes}

A similar diurnal pattern of food intake was found in both non-lactating and lactating rats, with over $80 \%$ being consumed during the dark period in both states but, at all times, intake was greater $(P<0 \cdot 001)$ in lactating than non-lactating rats (Fig. 1a). Serum leptin concentration was increased during the dark period in both non-lactating $(P<0 \cdot 001)$ and lactating $(P<0 \cdot 05)$ rats, but the increase 
( a )

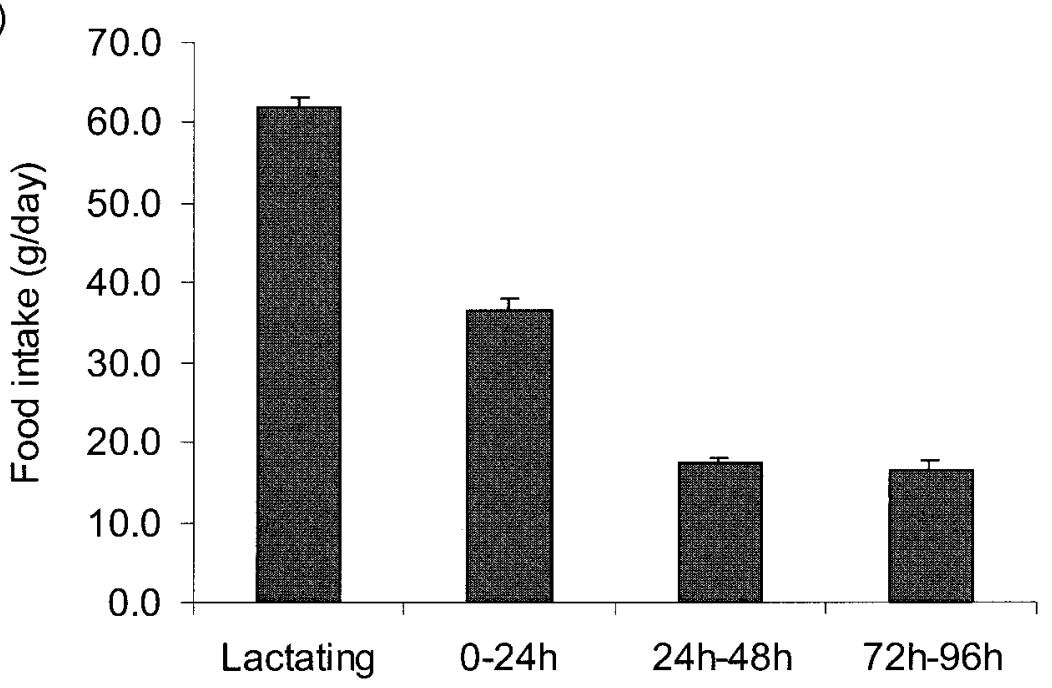

(b)

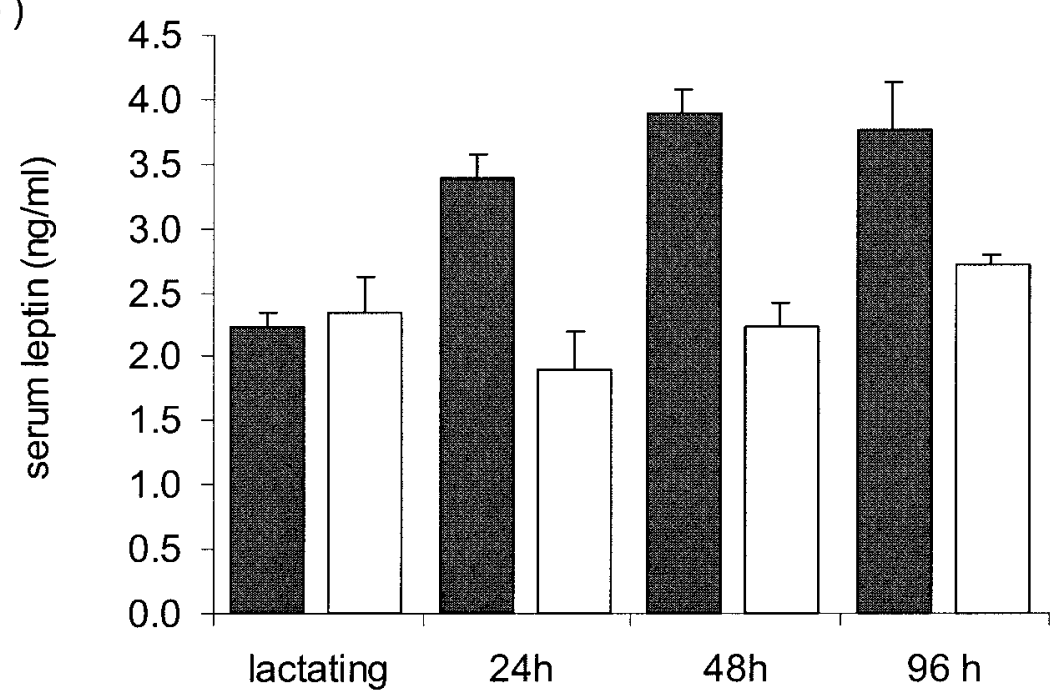

Figure 2 Effect of litter removal on (a) food intake and (b) serum leptin levels at night ( $2100 \mathrm{~h}$; shaded bars) and morning (0900 h; open bars). The light period was $0700 \mathrm{~h}$ to $1900 \mathrm{~h}$. Eight animals had their pups removed at $2100 \mathrm{~h}$. Food intake was measured over 24-h periods (2100-2100 h), starting $24 \mathrm{~h}$ before removing the litter. Blood samples were obtained by tail bleeding at $2100 \mathrm{~h}$ each day. A second group of five rats had their pups removed at $0900 \mathrm{~h}$; food intake was measured over 24-h periods $(0900-0900 \mathrm{~h})$ and blood was sampled each day at $0900 \mathrm{~h}$. All rats were killed $96 \mathrm{~h}$ after pup removal, and a further blood sample obtained. Results are expressed as means \pm S.E.M. of thirteen values (food intake), five values for daytime and eight values for night-time leptin.

was markedly smaller in lactating rats (43\%) than in non-lactating rats $(80 \%, P<0 \cdot 005)$ (Fig. $1 b)$.

\section{Effects of litter removal and replacement}

Removal of the litter at day 11 of lactation resulted in a rapid decrease $(P<0 \cdot 001)$ in food intake, with levels returning to those of non-lactating animals after $24 \mathrm{~h}$ of removal (Fig. 2a). The normal nocturnal rise in serum leptin, which was completely attenuated during lactation, was restored by $24 \mathrm{~h}$ after litter removal (Fig. 2b). Litter removal had no effect on daytime serum leptin concentrations (Fig. 2b). 
Table 1 Effects of litter removal for $48 \mathrm{~h}$ and litter restoration for $48 \mathrm{~h}$, on food intake, maternal weight, pup weight gain and nocturnal serum hormone concentrations. Pups were removed at $2100 \mathrm{~h}$ on day 13 of lactation, and fostered by other mothers prior to their return to their respective mothers $48 \mathrm{~h}$ later. Food intake was measured over each 24-h period (2100-2100 h). The light period was from $0700 \mathrm{~h}$ to $1900 \mathrm{~h}$. Maternal blood samples were obtained by tail bleeding at $2100 \mathrm{~h}$. Results were analysed by ANOVA and are means \pm S.E.M. of seven values unless otherwise stated. Results for five, age-matched control, non-lactating rats are also included; these values were compared with corresponding values for mothers using Student's $t$-test

\begin{tabular}{|c|c|c|c|c|}
\hline & \multicolumn{3}{|l|}{ Lactating } & \multirow{2}{*}{$\begin{array}{l}\text { Non-lactating } \\
\text { Control }\end{array}$} \\
\hline & Control & $\begin{array}{l}\text { Pups removed } \\
(48 \mathrm{~h})\end{array}$ & $\begin{array}{l}\text { Pups replaced } \\
(48 \mathrm{~h})\end{array}$ & \\
\hline Rat weight (g) & $296 \cdot 8 \pm 4 \cdot 8^{a}$ & $267 \cdot 6 \pm 4 \cdot 8^{b}$ & $283 \cdot 0 \pm 4 \cdot 8^{\mathrm{ab}}$ & $234 \cdot 6 \pm 7 \cdot 2^{c}$ \\
\hline Pup weight gain (g/day) & $1 \cdot 72 \pm 0 \cdot 18^{a}$ & & $0 \cdot 26 \pm 0 \cdot 18^{b}$ & \\
\hline Food intake (g/day) & $58 \cdot 0 \pm 1 \cdot 84^{a}$ & $18 \cdot 3 \pm 1 \cdot 84^{\mathrm{c}}$ & $38 \cdot 9 \pm 1 \cdot 84^{b}$ & $14 \cdot 5 \pm 1 \cdot 79^{\mathrm{C}}$ \\
\hline Leptin $(\mathrm{ng} / \mathrm{ml})$ & $2 \cdot 55 \pm 0 \cdot 20^{a}$ & $4 \cdot 11 \pm 0 \cdot 20^{b c}$ & $3 \cdot 64 \pm 0 \cdot 20^{b}$ & $4 \cdot 76 \pm 0 \cdot 38^{\mathrm{C}}$ \\
\hline Insulin (ng/ml) & $\begin{array}{l}1 \cdot 76 \pm 0 \cdot 65^{\mathrm{a}} \\
(n=5)\end{array}$ & $\begin{array}{l}3 \cdot 81 \pm 0 \cdot 73^{b} \\
(n=4)\end{array}$ & $\begin{array}{l}3 \cdot 85 \pm 0 \cdot 73^{b} \\
(n=4)\end{array}$ & $3 \cdot 62 \pm 0 \cdot 44^{b}$ \\
\hline $\mathrm{T}_{4}(\mathrm{nmol} / \mathrm{l})$ & $\begin{array}{l}23 \cdot 3 \pm 2 \cdot 40^{a} \\
(n=4)\end{array}$ & $\begin{array}{l}49 \cdot 3 \pm 2 \cdot 40^{\mathrm{b}} \\
(n=4)\end{array}$ & $\begin{array}{l}27 \cdot 6 \pm 2 \cdot 40^{a} \\
(n=4)\end{array}$ & $47 \cdot 8 \pm 4 \cdot 48^{b}$ \\
\hline
\end{tabular}

Values in a row without the same letter $(a, b, c)$ differ significantly $(P<0 \cdot 05)$.

If the litter was restored $48 \mathrm{~h}$ after removal from the mother, lactation was resumed and maternal food intake increased (Table 1). However, $48 \mathrm{~h}$ later, while litters were gaining weight (indicative of some milk production), both litter growth and food intake were much lower than before removal (Table 1). A substantial nocturnal increase in serum leptin concentration was apparent $48 \mathrm{~h}$ after litter removal, and was still present $48 \mathrm{~h}$ after re-initiation of suckling (Table 1). Both serum insulin and $\mathrm{T}_{4}$ increased after litter removal to levels found in non-lactating rats (Table 1). Serum $T_{4}$ fell to levels found in lactating rats by $48 \mathrm{~h}$ after re-initiation of suckling, whereas serum insulin concentration remained at the higher levels found after litter removal (Table 1).

\section{Effects of litter size}

Litter size was altered within $24 \mathrm{~h}$ of parturition to four, eight, ten and fourteen pups. Pup weight gain per day between days 10 and 13 of lactation was lower for litters of ten and fourteen pups than for smaller litters (Table 2). Total litter weight gain and maternal food intake both varied in proportion with litter size, being least in mothers suckling four pups and most in mothers suckling fourteen pups (Table 2). Food intake varied linearly with litter growth rate (Table 2). However, nocturnal serum leptin concentration did not vary consistently with litter size, and was significantly lower than in virgin control rats in all lactating groups (Table 2). Serum $\mathrm{T}_{4}$ concentrations were lower than those of virgin rats regardless of litter size and did not vary consistently with litter size (Table 2).

When litter size was reduced from ten to four pups on day 11 of lactation, food intake fell within $24 \mathrm{~h}$ to a level found in rats suckling only four pups throughout lactation (Fig. 3a and Table 2). There was also a transient increase in nocturnal serum leptin concentration $12 \mathrm{~h}$ after reduction of litter size, with the concentrations returning to the level found before litter size reduction by $36 \mathrm{~h}$ (Fig. 3b).

Table 2 Food intake, litter weight gain, maternal weight, nocturnal serum leptin and $\mathrm{T}_{4}$ concentrations of lactating rats suckling litters of different numbers of pups. Pup number was adjusted at birth to four $(n=4)$, eight $(n=4)$, ten $(n=3)$ or fourteen pups $(n=5)$. Results for age-matched, non-lactating, control rats $(n=4)$ are also included. Litter weight gain, food intake and maternal weight were measured daily over 3 days (days 11-14 of lactation) and mean values determined. Blood samples were taken by tail bleeding at $2100 \mathrm{~h}$ on day 11 of lactation. Statistical analysis was performed using ANOVA, with litter size as a factor. Results from the non-lactating group were compared with corresponding values for mothers using Student's t-test. Results are expressed as means \pm S.E.M.

\begin{tabular}{|c|c|c|c|c|c|}
\hline & Non-lactating & Four pups & Eight pups & Ten pups & Fourteen pups \\
\hline Litter weight gain (g/day) & - & $9 \cdot 81 \pm 0 \cdot 82^{\mathrm{a}}$ & $17 \cdot 5 \pm 0 \cdot 82^{\mathrm{b}}$ & $18 \cdot 6 \pm 0 \cdot 95^{\mathrm{b}}$ & $24 \cdot 7 \pm 0 \cdot 74^{c}$ \\
\hline Rat weight $(\mathrm{g})$ & $228 \pm 9 \cdot 60^{\mathrm{a}}$ & $260 \pm 5 \cdot 36^{b}$ & $305 \pm 5 \cdot 36^{c}$ & $292 \pm 6 \cdot 18^{c}$ & $301 \pm 4 \cdot 79^{c}$ \\
\hline Food intake (g/day) & $11 \cdot 7 \pm 0 \cdot 78^{\mathrm{a}}$ & $36 \cdot 5 \pm 1 \cdot 60^{\mathrm{b}}$ & $57 \cdot 5 \pm 1 \cdot 60^{c}$ & $58 \cdot 8 \pm 1 \cdot 84^{c}$ & $69 \cdot 7 \pm 1 \cdot 43^{d}$ \\
\hline Leptin $(\mathrm{ng} / \mathrm{ml})$ & $3 \cdot 89 \pm 0 \cdot 20^{\mathrm{a}}$ & $1 \cdot 79 \pm 0 \cdot 23^{b c}$ & $1 \cdot 36 \pm 0 \cdot 23^{b}$ & $1 \cdot 56 \pm 0 \cdot 27^{\mathrm{bc}}$ & $2 \cdot 03 \pm 0 \cdot 21^{\mathrm{c}}$ \\
\hline $\mathrm{T}_{4}(\mathrm{nmol} / \mathrm{l})$ & $47 \cdot 9 \pm 2 \cdot 83^{a}$ & $33 \cdot 2 \pm 3 \cdot 03^{b}$ & $25 \cdot 6 \pm 3 \cdot 03^{b c}$ & $23 \cdot 3 \pm 3 \cdot 49^{c}$ & $25 \cdot 2 \pm 2 \cdot 71^{\mathrm{bc}}$ \\
\hline
\end{tabular}

Values in a row without the same letter $(\mathrm{a}, \mathrm{b}$ and $\mathrm{c})$ differ significantly $(P<0 \cdot 05)$. 
(a)

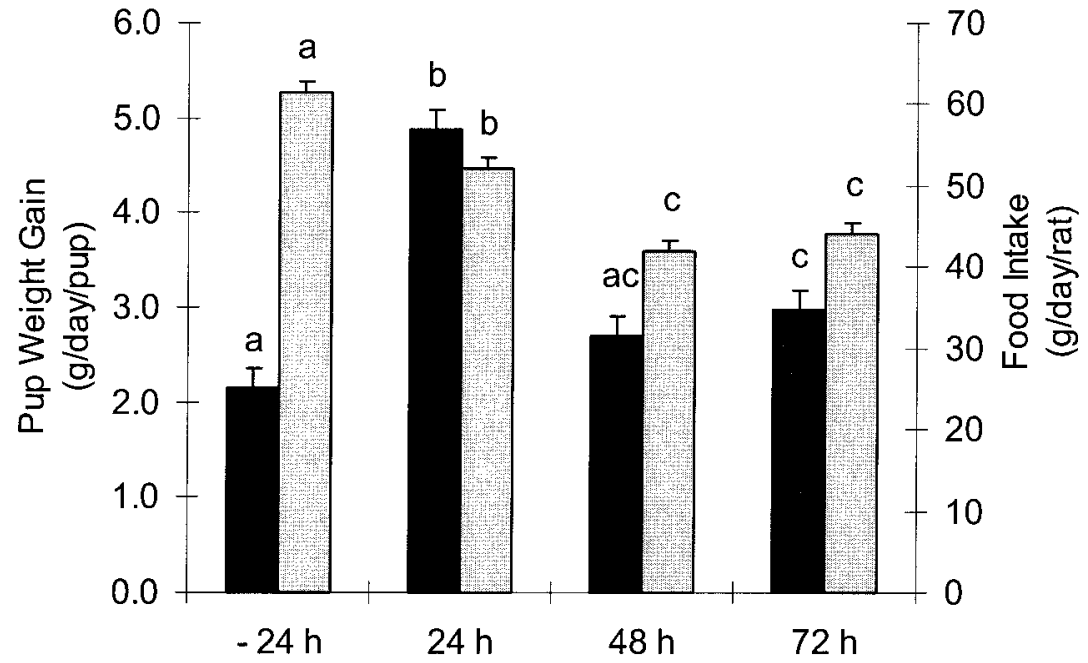

(b)

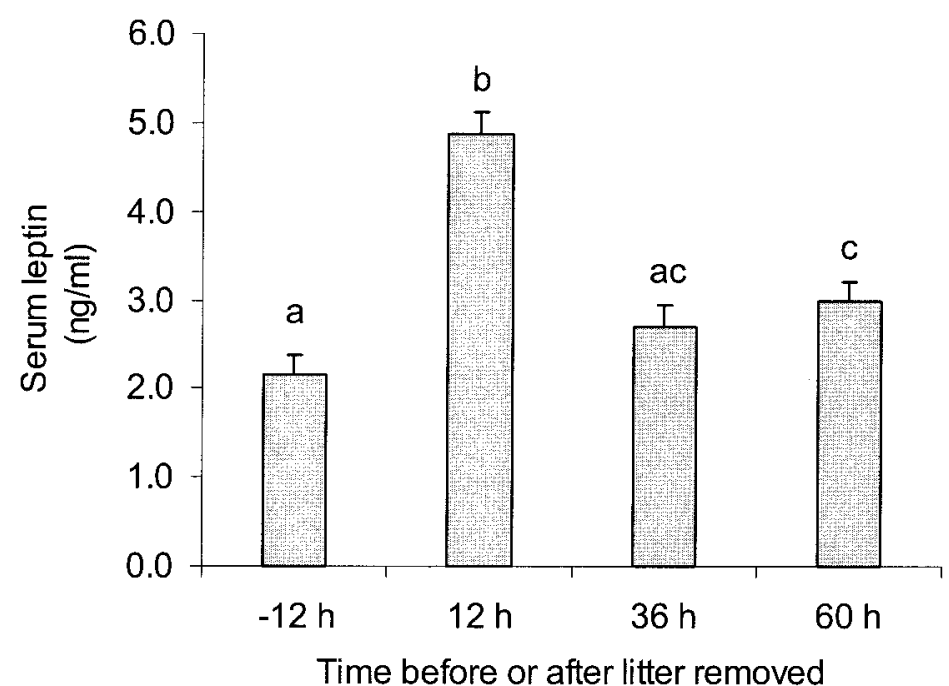

Figure 3 (a) Food intake (shaded bars) and pup growth (solid bars) and (b) nocturnal serum leptin concentrations following litter size reduction from ten pups to four pups at $0900 \mathrm{~h}$ on day 12 of lactation. Daily food intake and pup weight change values are from $0900 \mathrm{~h}$ to $0900 \mathrm{~h}$. Blood samples were collected every night at $2100 \mathrm{~h}$ by tail bleeding; the last value was obtained after killing the rats. All values are expressed as means \pm S.E.M. $(n=6)$. Statistical analyses were performed using ANOVA, for each variable, values (bars) without the same letter, $\mathrm{a}, \mathrm{b}$ and $\mathrm{c}$, differ significantly $(P<0 \cdot 05)$.

Pup weight gain also rose transiently during the first $24 \mathrm{~h}$ after reducing litter size from ten to four pups (Fig. 3a). Interestingly, the increase in weight of the whole litter of four pups over the $24 \mathrm{~h}$ after litter reduction $(20 \mathrm{~g} /$ day $)$ was similar to that for the ten-pup litter over the previous day $(22 \mathrm{~g} /$ day $)$. However, during the second day after reducing litter size, litter weight increased by only $11 \mathrm{~g} /$ day.

\section{Effects of giving a varied, high-energy diet}

Rats given a high-energy 'cafeteria diet' (cheese crackers, chocolate and peanuts plus standard chow) from parturition onwards consumed a similar weight of food over the first 4 days of lactation as rats fed standard chow. From day 5 onwards, the weight of food eaten per day was less in the rats fed the high-energy diet than in those fed standard 

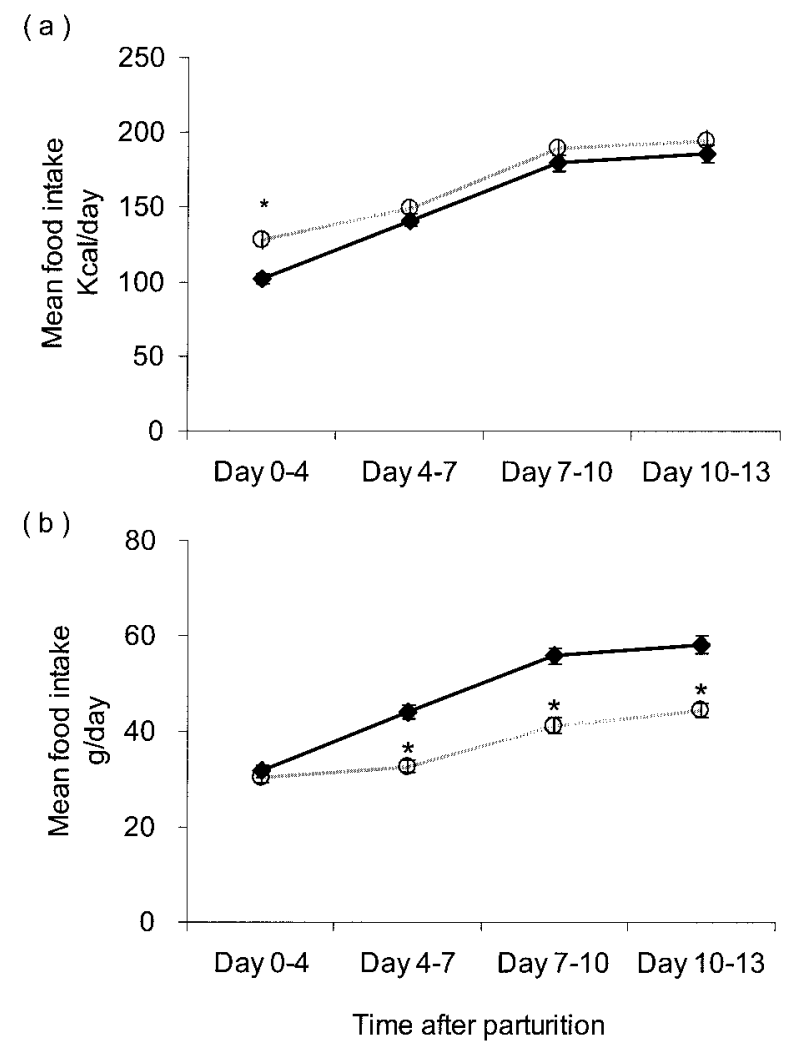

Figure 4 (a) Calorie intake (kcal/day) and (b) food intake (g/day) of lactating rats given, ad libitum, either a standard chow diet ( ) or a high-energy diet $(\bigcirc)$ composed of standard chow, cheese crackers, chocolate and peanuts. The amount of each individual component consumed over each period (parturition to day 4 of lactation, day 4 to day 7 , day 7 to day 10 and day 10 to day 13) was determined, and hence the total calorie intake was calculated. Values are expressed as means \pm S.E.M. of eight observations and were analysed by ANOVA, with diet and time after parturition as factors. * Significantly different $(P<0 \cdot 05)$ from that for rats fed standard chow.

chow (Fig. 4a), but daily energy intake was the same irrespective of diet (Fig. 4b). Pup growth was not altered by giving mothers the high-energy diet (results not shown). The high-energy diet had no significant effect on daytime or night-time serum leptin (Table 3). Neither daytime serum $\mathrm{T}_{4}$ concentration nor its normal nocturnal fall were altered by giving a high-energy diet (Table 3). However, giving a high-energy diet abolished the nocturnal rise in serum insulin concentration (Table 3 ).

\section{Effects of bromocriptine treatment}

Twice daily injections of bromocriptine for 2 days resulted in a decrease in pup weight gain (Table 4). Food intake also decreased with bromocriptine treatment but, after 2 days, intake remained more than double that of nonlactating rats (Table 4). Bromocriptine treatment increased
Table 3 Effects of feeding a high-energy diet on serum hormone concentrations in lactating rats. Rats were fed on either a standard chow diet or a high-energy diet from parturition. The light period was from $0700 \mathrm{~h}$ to $1900 \mathrm{~h}$. Blood was collected at $0900 \mathrm{~h}$ or $2100 \mathrm{~h}$ by tail bleeding on day 12 of lactation and after killing on day 14 of lactation. Half of the rats on each feeding regimen were tail-bled at $0900 \mathrm{~h}$ on day 12 and then were killed at $2100 \mathrm{~h}$ on day 14 and the other half bled at $2100 \mathrm{~h}$ on day 12 and killed at $0900 \mathrm{~h}$ on day 14 . ANOVA was performed with diet, time of the day and their interactions as factors. Values are expressed as means \pm S.E.M. of eight observations (leptin and insulin) or four observations $\left(\mathrm{T}_{4}\right)$

\begin{tabular}{|c|c|c|c|}
\hline & Time & Chow diet & Cafeteria diet \\
\hline \multicolumn{4}{|l|}{ Hormone } \\
\hline \multirow[t]{2}{*}{ Leptin (ng/ml) } & Day & $2 \cdot 18 \pm 0 \cdot 26^{a}$ & $2 \cdot 33 \pm 0 \cdot 26^{\mathrm{ab}}$ \\
\hline & Night & $2 \cdot 42 \pm 0 \cdot 26^{a b}$ & $3 \cdot 06 \pm 0 \cdot 26^{b}$ \\
\hline \multirow{2}{*}{ Insulin ( $\mathrm{ng} / \mathrm{ml})$} & Day & $1 \cdot 36 \pm 0.62^{a}$ & $1 \cdot 27 \pm 0.62^{\mathrm{a}}$ \\
\hline & Night & $5 \cdot 00 \pm 0.62^{b}$ & $1 \cdot 66 \pm 0.62^{\mathrm{a}}$ \\
\hline \multirow[t]{2}{*}{$\mathrm{T}_{4}(\mathrm{nmol} / \mathrm{l})$} & Day & $27 \cdot 79 \pm 1 \cdot 61^{\mathrm{b}}$ & $26 \cdot 43 \pm 1 \cdot 61^{\mathrm{ab}}$ \\
\hline & Night & $23 \cdot 17 \pm 1 \cdot 61^{\mathrm{a}}$ & $22.75 \pm 0.61^{a}$ \\
\hline
\end{tabular}

Values without the same letter $(a, b)$ differ significantly $(P<0 \cdot 05)$.

serum leptin concentration during both the dark and light periods, but the diurnal rhythm in serum leptin was not restored after 2 days of treatment (Table 4). Bromocriptine also increased serum insulin concentrations, but had no significant effect on serum $\mathrm{T}_{4}$ concentrations in lactating rats (Table 4). These effects of bromocriptine on food intake and serum leptin concentrations in lactating rats were confirmed in a second study in which the same dosage as before was continued for 3 days. After 3 days, pup growth had decreased to zero $(0 \cdot 0 \pm 0 \cdot 1 \mathrm{~g} /$ day $)$ but, despite this, maternal food intake was still $41.9 \pm$ $3.5 \mathrm{~g} /$ day (values are means \pm S.E.M. of eight observations). Serum leptin concentration in both the light and dark periods was increased by 3 days of bromocriptine treatment $(P<0 \cdot 01)$, but the nocturnal rise in serum leptin was still absent (leptin values: light, 1.55 and $2.46 \mathrm{ng} / \mathrm{ml}$ for saline and bromocriptine-treated rats; dark, 1.38 and $2.46 \mathrm{ng} / \mathrm{ml}$ for saline and bromocriptine-treated rats; results are means of four observations; S.E.D. 0-32).

In non-lactating rats bromocriptine treatment resulted in a small decrease in food intake and serum leptin, but did not have any effect on the nocturnal rise in serum leptin (Table 4). Bromocriptine treatment decreased daytime serum $\mathrm{T}_{4}$ in non-lactating rats, but had no effect on night-time levels (Table 4).

\section{Discussion}

Lactating rats are usually in marginal negative energy balance, mobilizing about $1 \mathrm{~g}$ adipose tissue lipid per day (Barber et al. 1997). Consistent with this, most studies have shown that serum leptin concentrations are decreased to some extent during lactation in rats (Kawai et al. 1997, 
Table 4 Effect of bromocriptine treatment on food intake, pup weight gain, serum leptin, $T_{4}$ and insulin concentrations in lactating and non-lactating rats. Groups of ten non-lactating rats and eight lactating rats were exposed to a light period from $0700 \mathrm{~h}$ to $1900 \mathrm{~h}$ or from $1900 \mathrm{~h}$ to $0700 \mathrm{~h}$. Half of each group was treated with saline and the other half with bromocriptine at $0900 \mathrm{~h}$ and $1700 \mathrm{~h}$ for 2 days. All animals were killed after $48 \mathrm{~h}$ of treatment, between $0900 \mathrm{~h}$ and $1000 \mathrm{~h}$ and trunk blood collected. Food intake and pup weight gain were measured over the $24 \mathrm{~h}$ before killing; values were analysed using Student's $t$-test. Values for serum hormones were analysed using ANOVA with state, time and treatment and their interactions as factors (serum leptin and $\mathrm{T}_{4}$ ) or state and treatment and their interactions (serum insulin). Results are expressed as means \pm S.E.M.

\begin{tabular}{|c|c|c|c|c|}
\hline & \multicolumn{2}{|l|}{ Lactating } & \multicolumn{2}{|l|}{ Non-lactating } \\
\hline & Saline & Bromocriptine & Saline & Bromocriptine \\
\hline Food intake (g/day) & $59 \cdot 9 \pm 2 \cdot 90^{\mathrm{a}}$ & $47 \cdot 7 \pm 1 \cdot 47^{b}$ & $15 \cdot 8 \pm 0 \cdot 30^{\mathrm{a}}$ & $13 \cdot 1 \pm 0 \cdot 38^{b}$ \\
\hline Pup weight gain (g/day) & $1 \cdot 82 \pm 0 \cdot 11^{\mathrm{a}}$ & $0 \cdot 81 \pm 0 \cdot 12^{\mathrm{b}}$ & - & - \\
\hline \multicolumn{5}{|l|}{ Serum leptin $(\mathrm{ng} / \mathrm{ml})$} \\
\hline Day & $\begin{array}{l}1 \cdot 56 \pm 0 \cdot 27^{a} \\
(n=4)\end{array}$ & $\begin{array}{l}2 \cdot 45 \pm 0 \cdot 27^{\mathrm{bc}} \\
(n=4)\end{array}$ & $\begin{array}{l}2 \cdot 78 \pm 0 \cdot 24^{c} \\
(n=5)\end{array}$ & $\begin{array}{l}1 \cdot 96 \pm 0 \cdot 24^{\mathrm{ab}} \\
(n=5)\end{array}$ \\
\hline Night & $\begin{array}{l}1 \cdot 82 \pm 0 \cdot 27^{\mathrm{ab}} \\
(n=4)\end{array}$ & $\begin{array}{l}2 \cdot 83 \pm 0 \cdot 27^{c} \\
(n=4)\end{array}$ & $\begin{array}{l}3 \cdot 91 \pm 0 \cdot 24^{\mathrm{d}} \\
(n=5)\end{array}$ & $\begin{array}{l}3 \cdot 18 \pm 0 \cdot 24^{c} \\
(n=5)\end{array}$ \\
\hline \multicolumn{5}{|l|}{$\mathrm{T}_{4}(\mathrm{nmol} / \mathrm{l})$} \\
\hline Day & $\begin{array}{l}36 \cdot 6 \pm 2 \cdot 66^{\mathrm{b}} \\
(n=4)\end{array}$ & $\begin{array}{l}34 \cdot 7 \pm 2 \cdot 66^{\mathrm{b}} \\
(n=4)\end{array}$ & $\begin{array}{l}45 \cdot 5 \pm 2 \cdot 38^{\mathrm{ac}} \\
(n=5)\end{array}$ & $\begin{array}{l}35 \cdot 9 \pm 2 \cdot 38^{\mathrm{b}} \\
(n=5)\end{array}$ \\
\hline Night & $\begin{array}{l}26 \cdot 7 \pm 2 \cdot 66^{\mathrm{a}} \\
(n=4)\end{array}$ & $\begin{array}{l}32 \cdot 8 \pm 2 \cdot 66^{\mathrm{ab}} \\
(n=4)\end{array}$ & $\begin{array}{l}41 \cdot 8 \pm 2 \cdot 66^{c} \\
(n=4)\end{array}$ & $\begin{array}{l}39 \cdot 2 \pm 2 \cdot 38^{\mathrm{bc}} \\
(n=5)\end{array}$ \\
\hline \multicolumn{5}{|l|}{ Insulin (ng/ml) } \\
\hline Night & $\begin{array}{l}0 \cdot 77 \pm 0 \cdot 62^{\mathrm{a}} \\
(n=4)\end{array}$ & $\begin{array}{l}4 \cdot 15 \pm 0 \cdot 62^{b} \\
(n=4)\end{array}$ & $\begin{array}{l}2 \cdot 18 \pm 0 \cdot 50^{\mathrm{ac}} \\
(n=5)\end{array}$ & $\begin{array}{l}3 \cdot 40 \pm 0 \cdot 50^{\mathrm{bc}} \\
(n=5)\end{array}$ \\
\hline
\end{tabular}

For each variable, values without the same letter (a, b, c and d) differ significantly $(P<0 \cdot 05)$.

Pickavance et al. 1998, Terada et al. 1998, Woodside et al. 1998, 2000, Brogan et al. 1999, Herrera et al. 2000, Johnstone \& Higuchi 2001). In addition, the nocturnal rise in serum leptin is usually completely lost during lactation, with a proportionally greater fall in serum leptin than seen during the daytime (Pickavance et al. 1998, Johnstone \& Higuchi 2001). The daytime hypoleptinaemia during lactation has been attributed to the drain on nutrients by the mammary gland, rather than being due to suckling (Brogan et al. 1999, Woodside et al. 2000); the present study supports this conclusion. In addition, we have shown that the attenuation of the nocturnal rise in serum leptin involves the suckling stimulus.

\section{Energy balance}

Varying energy balance in lactating rats usually involves altering suckling intensity, which complicates the interpretation of findings. However, our experiments, in which lactating rats were induced into positive energy balance, resulted in increased serum leptin concentrations, even though in most cases suckling continued.

Litter removal results in the immediate cessation of suckling and, although food intake decreases, rats move into positive energy balance, as shown by increased serum insulin and increased lipogenesis in white adipocytes (Agius et al. 1979, Flint et al. 1981). The diurnal rhythm in serum leptin is rapidly restored on litter removal. An increase in serum leptin on litter removal was found previously (Brogan et al. 1999, López-Soriano et al. 1999), but in these studies only daytime values were reported.

Milk production can be fully restored after litter removal by return of the pups; this takes 3 to 4 days in mice (Sorensen \& Knight 1997). Restoration of suckling $48 \mathrm{~h}$ after litter removal resulted in a substantial increase in food intake, and while levels found in rats with uninterrupted lactation were not achieved (at least by $48 \mathrm{~h}$ after litter replacement), intake was much greater than required for the low rate of pup growth. This suggests that these rats were in positive energy balance; consistent with this, serum insulin remained high, but serum $\mathrm{T}_{4}$ had returned to the low level found during lactation. A significant nocturnal rise in serum leptin occurred, achieving levels found in rats whose litters had been removed. Thus when rats are in substantial positive energy balance, serum leptin is elevated, despite a suckling stimulus.

Reducing litter number from ten to four pups resulted in a transient increase in nocturnal leptin. Again, this is probably due to the mothers moving briefly into positive energy balance as food intake remained high during the first day after litter reduction.

Bromocriptine treatment suppresses prolactin secretion and milk production in rats (Cowie et al. 1980). Milk production did not stop completely, even after 3 days of treatment with bromocriptine (if it had, pups would have lost weight). However, such treatment only slightly decreased food intake, which greatly exceeded the estimated need (from Table 2) for the decreased rate of pup 
growth. This implies that the mothers moved into positive energy balance. Consistent with this, serum insulin levels were increased as found previously (Agius et al. 1979, Flint et al. 1981). Other studies have shown that bromocriptine treatment increases adipocyte lipogenesis in lactating rats (Agius et al. 1979, Flint et al. 1981), again indicating a move into positive energy balance. Serum leptin concentration increased during bromocriptine treatment, but the diurnal rhythm of leptin secretion was not restored. The effect of bromocriptine on serum leptin was not due to a fall in serum prolactin, as prolactin increases leptin secretion (Gualillo et al. 1999).

Thus, in several situations where mothers move into positive energy balance, serum leptin concentration increases, although the diurnal rhythm of leptin secretion is not always restored. These findings support the view (Brogan et al. 1999, Woodside et al. 2000) that altered energy balance is a major cause of the daytime hypoleptinaemia of lactation. Differences in the degree of negative energy balance could account for why the effects of lactation on serum leptin are quantitatively very variable (0-75\% decrease) depending on the study (Chien et al. 1997, Kawai et al. 1997, Pickavance et al. 1998, Terada et al. 1998, Woodside et al. 1998, 2000, Brogan et al. 1999, Carmen-Garcia et al. 2000, Herrera et al. 2000, Johnstone \& Higuchi 2001).

We also tried to induce positive energy balance by giving mothers a varied, high-energy diet to facilitate increased energy intake. However, after a brief adjustment period, the mothers decreased the weight of food eaten relative to others given just the chow diet, but both groups consumed a similar number of calories. We conclude that in rats the negative energy balance of lactation is not due to a physical constraint on intake, as those given the high-energy diet could clearly have consumed more food. Consistent with this, in the study in which litter size was varied, rats suckling ten pups could have increased their intake $(59 \mathrm{~g} /$ day) to the level found in those suckling fourteen $(70 \mathrm{~g} /$ day $)$, which would probably be enough to counteract the energy deficit.

\section{Suckling stimulus}

Food intake in lactating rats varies with litter size and hence growth rate (Ota \& Yokoyama 1967, Issler et al. 1984), but the signals linking intake and mammary output have not been defined. There are afferent nerves from the nipple to various regions of the brain and hypothalamus, including the paraventricular nucleus, which mediate the effects of suckling on oxytocin and prolactin secretion (Grosvenor \& Mena 1974). These nerves could also transmit signals to regulate intake, for the paraventricular nucleus is a key centre co-ordinating signals regulating appetite (Williams et al. 2001). In addition, there may also be chemical signals from the mammary gland to centres of appetite control. Cutting of the galactophores (milk ducts) or removal of the nipples results in a decrease in food intake in lactating animals (Flemming 1976, Mann et al. 1983, Woodside et al. 2000). This effect could be due to severance of afferent nerves to the hypothalamus or accumulation of milk within the gland leading to altered signalling by chemical mediators. In the present study, food intake remained relatively high in mothers treated with bromocriptine, even though milk production was markedly reduced; pups would be hungry and so would be expected to maintain a strong suckling stimulus. Similarly, restoration of litters after they had been removed from their mothers for $48 \mathrm{~h}$ increased food intake more than was required for the amount of milk being produced. These observations suggest that suckling can increase appetite in lactating rats, independent of milk production, probably by transmission of a signal from the nipple to the hypothalamus via the nervous system.

While suckling is an important stimulant of food intake, it does not seem to have an effect on daytime serum leptin levels, or at least any effects are easily counteracted by positive energy balance. Thus bromocriptine treatment resulted in an increase in daytime serum leptin in lactating rats, despite continued suckling. Cutting the galactophores increased daytime serum leptin in lactating rats (Woodside et al. 2000); as in the present study, there was a rise in serum insulin and also an increase in fat pad weight, indicating that the rats had moved into positive energy balance (Woodside et al. 2000). Similarly, litter restoration failed to decrease daytime leptin levels in rats in which milk production was not reinitiated; again the high serum insulin levels suggest that these rats were in positive energy balance (Brogan et al. 1999).

Although bromocriptine treatment increased serum leptin levels, such treatment did not restore the diurnal rhythm of leptin secretion. This suggests that the loss of rhythm is due in part at least to the suckling stimulus. The failure to restore the nocturnal rise is not an artifact of bromocriptine treatment itself, as the drug did not attenuate the diurnal rhythm of leptin secretion in non-lactating rats. However, litter restoration for $48 \mathrm{~h}$ after removal, while achieving similar litter growth and food intake as bromocriptine treatment for $48 \mathrm{~h}$, did not prevent the diurnal rhythm of leptin secretion. This could be due to the mechanism not being fully restored $48 \mathrm{~h}$ after litter replacement.

The suckling stimulus was also varied by altering litter size, but this had no effect on the low nocturnal leptin level, which was similar in rats suckling from four to fourteen pups. Possibly the suckling stimulus induced by just four pups was sufficient to achieve a maximum effect on the serum leptin level.

\section{Leptin and the hyperphagia of lactation}

Lactation results in increased expression of both neuropeptide Y (Ciofi et al. 1991, Pelletier \& Tong 1992, Smith 1993, Malabu et al. 1994, Pape \& Tramu 1996, Wilding 
et al. 1997, Li et al. 1998, Chen et al. 1999) and agouti-related peptide (Chen et al. 1999), and decreased expression of pro-opiomelanocortin (Smith 1993, Pape \& Tramu 1996). These changes in hypothalamic neuropeptide gene expression are consistent with the hypoleptinaemia and should promote hyperphagia (Ahima 2000, Ahima \& Flier 2000, Ahima et al. 2000, Havel 2000, Spiegelman \& Flier 2001, Williams et al. 2001). However, leptin would not appear to have a direct role in causing the hyperphagia, because varying litter size resulted in changes in food intake without any apparent change in serum leptin. Furthermore, suckling can increase food intake despite an increase in serum leptin. Thus the hypoleptinaemia of lactation appears to have a permissive role, facilitating the hyperphagia, rather than being a direct cause.

\section{Leptin and $T_{4}$}

In addition to its effects on appetite, leptin also modulates the secretion of pituitary hormones (Ahima 2000, Ahima \& Flier 2000, Ahima et al. 2000, Flier et al. 2000). Treatment with leptin partly prevented the fall in serum $\mathrm{T}_{4}$ on fasting (Ahima 2000). Thyroid hormones increase basal metabolic rate (Shetty 1990) and may also enhance brown adipose tissue thermogenesis (Silva 1993). Undernutrition results in decreased energy expenditure, which is at least partly due to the concomitant hypothyroidism (Shetty 1990). Thus the hypoleptinaemia of lactation could contribute to the hypothyroidism, and hence increased metabolic efficiency of the state. Indeed, with one exception (litter restoration), serum leptin and $\mathrm{T}_{4}$ changed in parallel in the present study. Notably, varying litter size from four to fourteen pups, which altered food intake, had no effect on the degree of hypoleptinaemia or hypothyroidism. In general, changes in energy balance were accompanied by changes in serum $\mathrm{T}_{4}$ and leptin levels.

\section{Conclusions}

The hypoleptinaemia of lactation may facilitate the hyperphagia, but the suckling signal, and possibly other signals from the mammary gland, would appear to be more important determinants of appetite. Curiously, while there is a clear relationship between milk production and food intake, lactating rats are usually in slight negative energy balance; this is not due to a physical constraint on intake. This negative energy balance is a major factor causing the hypoleptinaemia of lactation, and differences in the degree of negative energy balance could explain why the degree of daytime hypoleptinaemia varies quite markedly between reported studies. By contrast, the suckling stimulus is involved in the suppression of the nocturnal rise in leptin. The hypoleptinaemia probably not only facilitates the hyperphagia, but may also be the cause of the hypothyroidism of lactation and hence the increased metabolic efficiency of the state.

\section{Acknowledgements}

We thank Mr S McBlane and Mrs S Paton for care of the animals. We thank Dr S Brocklehurst, Biomathematics and Statistics Scotland, for statistical advice. The study was funded by the Scottish Executive Environment and Rural Affairs Department.

\section{References}

Agius L, Robinson AM, Girard JR \& Williamson DH 1979 Alterations in the rate of lipogenesis in vivo in maternal liver and adipose tissue on premature weaning of lactating rats. Biochemical Journal 180 689-692.

Ahima RS 2000 Leptin and the neuroendocrinology of fasting. Frontiers in Hormonal Research 26 42-56.

Ahima RS \& Flier JS 2000 Adipose tissue as an endocrine organ. Trends in Endocrinology and Metabolism 11 327-332.

Ahima RS, Saper CF, Flier JS \& Elmquist JK 2000 Leptin regulation of neuroendocrine systems. Frontiers in Neuroendocrinology 21 263-307.

Barber MC, Clegg RA, Travers MT \& Vernon RG 1997 Lipid metabolism in the lactating mammary gland. Biochimica et Biophysica Acta 1347 101-126.

Brogan RS, Mitchell SE, Trayhurn P \& Smith MS 1999 Suppression of leptin during lactation: contribution of the suckling stimulus versus milk production. Endocrinology 140 2621-2627.

Bruckdorfer KR, Kang SS, Khan IH, Bourne AR \& Yudkin J 1974 Diurnal changes in the concentrations of plasma lipids, sugars, insulin and corticosterone in rats fed diets containing various carbohydrates. Hormone and Metabolic Research 6 99-106.

Carmen-Garcia MD, Casanueva FF, Dieguez C \& Senaris RM 2000 Gestational profile of leptin messenger ribonucleic acid (mRNA) content in the placenta and adipose tissue in the rat, and regulation of the mRNA levels of the leptin receptor subtypes in the hypothalamus during pregnancy and lactation. Biology of Reproduction 62 698-703.

Chen P, Li C, Haskell-Luevano C, Cone RD \& Smith MS 1999 Altered gene expression of agouti-related protein and its colocalization with neuropeptide $\mathrm{Y}$ in the arcuate nucleus of the hypothalamus during lactation. Endocrinology 140 2645-2649.

Chien EK, Hara M, Rouard M, Yano H, Phillipe M, Polonsky KS \& Bell GI 1997 Increased serum leptin and uterine leptin receptor messenger RNA levels during pregnancy in rats. Biochemical and Biophysical Research Communications 237 476-480.

Chilliard Y 1986 Revue bibliographique: variations quantitatives et métabolisme des lipides dans les tissus adipeux et le foie au cours du cycle gestation-lactation. 1. Chez la ratte. Reproduction, Nutrition, Development 26 1057-1103.

Ciofi P, Fallon JH, Croix D, Pollak JM \& Tramu G 1991 Expression of neuropeptide $\mathrm{Y}$ precursor - immunoreactivity in the hypothalamic dopaminergic tubero-infundibular system during lactation in rodents. Endocrinology 128 823-834.

Cowie AT, Forsyth IA \& Hart IC 1980 Hormonal Control of Lactation, pp 165-168. Berlin, Germany: Springer-Verlag.

Fleming AS 1976 Control of food intake in the lactating rat: role of suckling and hormones. Physiology and Behaviour 17 841-848.

Flier JS, Harris M \& Hollenberg AN 2000 Leptin, nutrition, and the thyroid: the why, the wherefore and the wiring. Journal of Clinical Investigation 105 859-861.

Flint DJ, Clegg RA \& Vernon RG 1981 Prolactin and the regulation of adipose tissue metabolism during lactation in rats. Molecular and Cellular Endocrinology 22 265-275.

Grosvenor CE \& Mena F 1974 Neuroendocrine control of lactation. In Lactation: A Comprehensive Treatise, vol 1, pp 227-276. Eds BL Larson \& VR Smith. New York, USA: Academic Press.

Gualillo O, Lago F, Garcia M, Menendez C, Senaris R, Casanueva FF \& Dieguez C 1999 Prolactin stimulates leptin secretion by rat white adipose tissue. Endocrinology 140 5149-5153. 
Havel PJ 2000 Role of adipose tissue in body-weight regulation: mechanisms regulating leptin production and energy balance. Proceedings of the Nutrition Society 59 359-371.

Herrera E, Lasunción, Huerta L \& Martín-Hidalgo A 2000 Plasma leptin levels in rat mother and offspring during pregnancy and lactation. Biology of the Neonate 78 315-320.

Isler D, Trayhurn P \& Lunn PG 1984 Brown adipose tissue metabolism in lactating rats: the effect of litter size. Annals of Nutrition and Metabolism 28 101-109.

Johnstone LE \& Higuchi T 2001 Food intake and leptin during pregnancy and lactation. Progress in Brain Research 133 215-227.

Kalsbeek A, Fliers E, Romijn JA, La Fleur SE, Wortel J, Bakker O, Endert E \& Buijs RM 2001 The suprachiasmatic nucleus generates the diurnal changes in plasma leptin levels. Endocrinology 142 2677-2685.

Kawai M, Yamaguchi M, Murakami T, Shima K, Murata Y \& Kishi K 1997 The placenta is not the main source of leptin production in pregnant rat: gestational profile of leptin in plasma and adipose tissues. Biochemical and Biophysical Research Communications 240 798-802.

Kimura T, Maji T \& Ashida K 1970 Periodicity of food intake and lipogenesis in rats subjected to two different feeding plans. Journal of Nutrition 100 691-697.

Li C, Chen P \& Smith MS 1998 The acute suckling stimulus induces expression of neuropeptide Y (NPY) in cells in the dorsomedial hypothalamus and increases NPY expression in the arcuate nucleus. Endocrinology 139 1645-1652.

López-Soriano J, López-Soriano FJ, Carbó N \& Argilés JM 1999 Leptin administration to lactating rats is unable to induce changes in lipid metabolism in white adipose tissue or mammary gland. European Journal of Obstetrics, Gynecology and Reproductive Biology 84 93-97.

McNamara JP 1995 Role and regulation of metabolism in adipose tissue during lactation. Nutritional Biochemistry 6 120-129.

Mann MA, Miele JL, Kinsley CH \& Svare B 1983 Postpartum behavior in the mouse: the contribution of suckling stimulation to water intake, food intake and body weight regulation. Physiology and Behaviour 31 633-638.

Malabu U, Kilpatrick A, Ware M, Vernon RG \& Williams G 1994 Increased neuropeptide $\mathrm{Y}$ concentrations in specific hypothalamic regions of lactating rats: possible relationships to hyperphagia and adaptive changes in energy balance. Peptides 15 83-87.

Mastronardi CA, Walczewska A, Yu WH, Karanth S, Parlow AF \& McCann SM 2000 The possible role of prolactin in the circadian rhythm of leptin secretion in male rats. Proceedings of the Society for Experimental Biology and Medicine 224 152-158.

Munday MR \& Williamson DH 1983 Diurnal variations in food intake and in lipogenesis in mammary gland and liver of lactating rats. Biochemical Journal 214 183-187.

Nagatani S, Guthikonda P \& Foster DL 2000 Appearance of a nocturnal peak of leptin secretion in the pubertal rat. Hormones and Behaviour 37 345-352.

Nishiyama M, Makino S, Suemaru S, Nanamiya W, Asaba K, Kaneda T, Mimoto T, Nishioka T, Takao T \& Hashimoto K 2000 Glucocorticoid effects on the diurnal rhythm of circulating leptin levels. Hormone Research 54 69-73.

Ota K \& Yokoyama A 1967 Body weight and food consumption of lactating rats nursing various sizes of litters. Journal of Endocrinology 38 263-268.

Pape JR \& Tramu G 1996 Suckling-induced changes in neuropeptide $\mathrm{Y}$ and proopiomelanocortin gene expression in the arcuate nucleus of the rat: evaluation of a putative intervention of prolactin. Neuroendocrinology 63 540-549.

Pelletier G \& Tong Y 1992 Lactation but not prolactin increases the levels of pre-proNPY mRNA in the rat arcuate nucleus. Molecular and Cellular Neurosciences 3 286-290.
Pickavance L, Dryden S, Hopkins D, Bing C, Frankish H, Wang Q, Vernon RG \& Williams G 1996 Relationships between hypothalamic neuropeptide $\mathrm{Y}$ and food intake in the lactating rat. Peptides 17 577-582.

Pickavance L, Tadayyon M, Williams G \& Vernon RG 1998 Lactation suppresses diurnal rhythm of serum leptin. Biochemical and Biophysical Research Communications 248 196-199.

Pu S, Dube MG, Kalra PS \& Kalra SP 2000 Regulation of leptin secretion: effects of aging on daily patterns of serum leptin and food consumption. Regulatory Peptides 92 107-111.

Saladin R, De Vos P, Guerre-Millo M, Leturque A, Girard J, Staels B \& Auwerx J 1995 Transient increase in obese gene expression after food intake or insulin admnistration. Nature 377 527-529.

Shetty PS 1990 Physiological mechanisms in the adaptive response of metabolic rates to energy restriction. Nutrition Research Reviews 3 49-74.

Silva JE 1993 Hormonal control of thermogenesis and energy dissipation. Trends in Endocrinology and Metabolism 4 25-32.

Smith MS 1993 Lactation alters neuropeptide Y and proopiomelanocortin gene expression in the arcuate nucleus of the rat. Endocrinology 133 1258-1265.

Sorensen A \& Knight CH 1997 Restoration in mice after litter removal for various lengths of time. Journal of Reproduction and Fertility (Abstracts) 1946.

Spiegelman BM \& Flier JS 2001 Obesity and the regulation of energy balance. Cell 104 531-543.

Strubbe JH \& Gorissen J 1980 Meal patterning in the lactating rat. Physiology and Behaviour 25 775-777.

Terada Y, Yamakawa K, Sugaya A \& Toyoda N 1998 Serum leptin levels do not rise during pregnancy in age-matched rats. Biochemical and Biophysical Research Communications 253 841-844.

Trayhurn P 1989 Thermogenesis and the energetics of pregnancy and lactation. Canadian Journal of Physiology and Pharmacology 67 370-375.

Vernon RG \& Pond CM 1997 Adaptations of maternal adipose tissue to lactation. Journal of Mammary Gland Biology and Neoplasia 2 231-241.

Wade GN \& Schneider JE 1992 Metabolic fuels and reproduction in female mammals. Neuroscience and Behaviour Review 16 235-275.

Wilding JPH, Ajala MO, Lambert PD \& Bloom SR 1997 Additive effect of lactation and food restriction to increase hypothalamic neuropeptide Y mRNA in rats. Journal of Endocrinology 152 365-369.

Williams G, Bing C, Cai XJ, Harrold JA, King PJ \& Liu XH 2001 The hypothalamus and the control of energy homeostasis: different circuits, different purposes. Physiology and Behaviour 74 683-701.

Williamson DH \& Lund P 1994 Cellular mechanisms for the regulation of adipose tissue lipid metabolism in pregnancy and lactation. In Nutrient Regulation during Pregnancy, Lactation and Infant Growth, pp 39-64. Eds L Allen, J King \& B Lönnerdal. New York, USA: Plenum Press.

Woodside B, Abizaid A \& Jafferali S 1998 Effect of acute food deprivation on lactational infertility in rats is reduced by leptin administration. American Journal of Physiology 274 R1653-R1658.

Woodside B, Abizaid A \& Walker C-D 2000 Changes in leptin levels during lactation: implications for lactational hyperphagia and anovulation. Hormones and Behaviour 37 353-365.

Xu B, Kalra PS, Farmerie WG \& Kalra SP 1999 Daily changes in hypothalamic gene expression of neuropeptide Y, galanin, proopiomelanocortin and adipocytes leptin gene expression and secretion: effects of food restriction. Endocrinology 140 2868-2875.

Zhang Y, Procena R, Barone M, Leopold L \& Friedman JM 1994 Positional cloning of the mouse obese gene and its human homologue. Nature 372 425-432.

Received 9 September 2002 Accepted 22 October 2002 